\title{
Flora da Reserva Ducke Amazonas, Brasil: Rhizophoraceae
}

Ghillean T. Prance ${ }^{1}$

Rhizophoraceae R. Br., in Flinders, Voy. Terra Austr. 2: 549. 1814. Nom. cons.

Engler, A., in Mart. Fl. bras. 12(2); 424-432. 1876.

Prance, G. T.; Silva, M. F.; Albuquerque, B. W.; Araujo, I. J. S.; Carreira, L. M.; Braga, M. M. N.; Macedo, M.; Conceicao, P. N.; Lisboa, P. L. B.; Braga, P. I.; Lisboa, R. C. L.; Vilhena, R. C. Q. Revisão taxonômica das espécies amazônicas de Rhizophoraceae. Acta Amazonica 5(1): 5-22. 1975.

Trees or shrubs. Leaves opposite, in pairs or verticels entire, with single midrib. Stipules present, interpetiolar, sheathing the terminal bud, caducous. Flowers solitary and axillary or in axillary few-flowered cymes or racemes or a dichotomous, corymbose panicle, hermaphrodite or dioecious, actinomorphic, perigynous or epigynous; sepals 4-7, valvate; petals $4-7$, alternate with sepals, and usually shorter, fimbriate or laciniate; stamens 8-40, twice or 3-4 times as many as petals, borne in a single ring, often in pairs opposite the petals, inserted around the base of a perigynous nectary disk, or disk rarely absent, free or connate at base; anthers introrse, longitudinally dehiscent, dorsifixed; ovary superior in Reserve Ducke genera, or inferior, 2-6 locular,
1-2 ovules per loculus; ovule anatropous, pendulous; style terminal, stigma 3-4 lobed. Fruit a drupe or capsule with 1 seed or 1-2 seeds per locule, in the mangrove genera embryo straight, linear, green and viviparous; endosperm present.

The family consists of 14 genera and about one hundred species distributed around the tropics. Three genera occur in Amazonia, Rhizophora which is confined to coastal mangrove forest, Cassipourea and Sterigmapetalum both of which are present in the Reserva Ducke.

The mangrove species of Rhizophora have been much used for timber, firewood and charcoal and as a source of tannins for leather. There are no recorded uses of Cassipourea and Sterigmapetalum in Central Amazonia.

\section{Key to the species of Rhizophoraceae of Reserva Ducke}

1. Leaves opposite; petals spathulate; inflorescence of solitary flowers or borne in sessile clusters, hermaphrodite 1.1 Cassipourea guianensis

1. Leaves verticellate; petals laciniate; inflorescence a corymbose panicle with long pedicel; flowers dioecious 2.1 Sterigmapetalum obovatum

\section{Cassipourea}

Cassipourea Aubl., Hist. Pl. Guiane 1: 529. 1775. 1788.

Legnotis Swartz, Prod. Fl. Ind. Occ.: 84.

Trees or shrubs. Leaves opposite and decussate; stipules interpetiolar, caducous. Inflorescences solitary flowers or fasciculate groups, axillary, sessile or pedicellate; bracts present at base of pedicel. Flowers hermaphrodite; disk fleshy or membraneous, dentate; calyx tube campanulate, 4-5-lobed, the lobes erect, valvate; petals 4-5, unguiculate, fimbriate, folded in bud, white; stamens 8-40, inserted around margin of disk; ovary superior, free, inserted at the base of calyx tube, sericeouspilose, 2-4 locular with two ovules per locule; style filiform, erect, stigma 3-4 lobed or capitate. Fruit an ovoid capsule, 3-4 locular with 1 or rarely two seeds per locule, embryo erect.

A pantropical genus of about 70 species, mainly African with ten species in the

Artigo recebido em 9/2004. Aceito para publicação em 04/2005.

${ }^{1}$ Royal Botanic Gardens, Kew Richmond, Surrey, TW9 3AB, Great Britain. 
Neotropics, three of which occur in Amazonia and two in Central Amazonia. One species occurs in Reserva Ducke.

1.1 Cassipourea guianensis Aubl., Pl. Guiane Franc. 1: 529. 1775.

Cassipourea spruceana Benth. ex Engl., in Mart. Fl. bras. 12(2): 429. 1876.

Legnotis cassipourea Swartz, Fl. Ind. Occ. 2: 970. 1800.

Tree to $6 \mathrm{~m}$ tall. Leaves elliptic to oblong-lanceolate, subcoriaceous, $4.5-23.5 \mathrm{~cm}$ long, $2.5-9.5 \mathrm{~cm}$ broad, glabrous above, with few hairs on venation beneath, apex acuminate, base cuneate to rounded; primary veins 6-12 pairs, plane above, prominulous beneath, anastomosing near margins. Inflorescence of axillary glomerules. Flowers sessile; calyx 4-5 lobed, sparsely pubescent on exterior, densely pilose within; petals 4-5, unguiculate, white; stamens numerous, $c$. 20, free to base; ovary densely pilose; style filiform, pilose at base; stigma capitate. Fruit a capsule.

Type: Aublet s.n., French Guiana (holotype, $\mathrm{BM})$.

Varzea forest and stream margins in Venezuela, Trinidad, the Guianas and Brazilian Amazonia.

Flowering from June to November.

6.VI.1993 (fl) Ribeiro, J. E. L. S. et al. 895 (INPA K MGMONY RB SPU).

\section{Sterigmapetalum}

Sterigmapetalum Kuhlm., Arch. Jard. Bot. Rio de Janeiro 4: 359. 1925.

Small to large trees. Leaves 2-5 verticellate; stipules interpetiolar or axillary, coriaceous. Inflorescence of pedunculate, corymbose, dichotomous panicles, with bracts and bracteoles. Flowers dioecious; calyx 6-7 lobed in female flowers, 5-6 lobed in male flowers; petals laciniate into 3 parts, similar in flowers of both sexes; stamens 10-12, the filaments shortly villous towards base, vestigial ovaries only in male flowers; ovary in female flowers obovoid, sericeous, 5-6 locular with 2 ovules in each locule. Fruit an obovate-oblong capsule, 5-6 locular with 2 seeds in each locules, septicidal.

A genus of three species in northern Colombia, the Guianas and Central Amazonia west to Iquitos, Peru. One species occurs in Reserva Ducke.

2.1 Sterigmapetalum obovatum Kuhlm., Arch. Jard. Bot. Rio de Janeiro 4: 360. 1925.

Small to large tree. Leaves 3-5 verticellate, obovate, $9-17 \mathrm{~cm}$ long, $4.5-9 \mathrm{~cm}$ broad, glabrous above, densely pilose beneath, emarginate to acute at apex, primary veins 11 15 pairs, impressed above, prominent beneath, secondary venation conspicuously reticulate on both surfaces; petioles $0.5-2 \mathrm{~mm}$ long, pilose. Inflorescence a corymbose panicle borne in axils of upper leaves; peduncles, pedicels and calyx densely short-sericeous; peduncles 3-6 cm long, bracteolate. Male flowers sessile, the calyx 5-6 mm long, 3$4 \mathrm{~mm}$ wide; calyx of female flowers growing after pollination to $5-6 \times 7-8 \mathrm{~mm}$, the lobes sericeous within; petals in both sexes linear, flagelliform-laciniate, $10-12 \times 1.5 \mathrm{~mm}$, glabrous, white; vestigial ovary of male flower and ovary of female flower both densely sericeous. Fruit an oblong-ovate capsule, shortly sericeous on exterior, $4 \mathrm{~cm}$ long, $2-2.5 \mathrm{~cm}$ broad.

Type: J. G. Kuhlmann 375 fl. fem. (lectotype, $\mathrm{RB})$.

Central Amazonia and west to Iquitos, Peru, a species of forest on terra firme.

Flowering from September to November, fruiting from December to March. 15.IX.1994 (fl) Ribeiro, J. E. L. S. et al. 1423 (INPA KMG MO NY RB SP U); 19. III.1968 (fr) Rodrigues, W. et al. 8468 (INPA); 24.VIII.1994 (bd) Sothers, C. A. et al. 132 (G INPA K MG UB US); 27.IX.1995 (fl) Sothers, C. A. et al. 582 (BM F INPA K MBM MG UFMT); 22.IX.1995 (fl) Vicentini, A. \& Silva, C. F. 1060 (B INPA K MG PUEFR R UB UEC VEN). 
